\title{
WHO SHOULD BE A PARENT? PARENTHOOD AND THE SIG- NIFICANCE OF REPRODUCTIVE CHOICE
}

\author{
Claire Junga $\mathrm{Kim}^{1}$
}

\begin{abstract}
The various reproductive technologies have expanded the power people have to control their bodily function. Because these technologies have brought new configurations of people whose role is central to the reproductive process, ambiguities about the attribution of parenthood have emerged. I insist that the intentional account among four explanatory frameworks for parenthood gains more validity, as opportunities to exert intention increase. I extend the intentional account, using Scanlon's explanation of the "Value of Choice." In the Value of Choice, Scanlon explains that choice has a justificatory power; that is, by the fact of having choice, one accepts the normative consequences of one's decision. The current changes in reproduction technologies mean that there are several conditions to choose. While maintaining justificatory power from the Value of Choice, the intentional account becomes inclusive enough to encompass the status quo, plausible even in situations where intention does not exist or is not exerted.
\end{abstract}

Key words: parents, parenthood status, reproduction, reproductive technology, assisted reproductive techniques

\section{¿Quién debería ser padre? Paternidad y la importancia de elección reproductiva}

Resumen: La variedad de tecnologías reproductivas han expandido el poder que las personas tienen para controlar su función corporal. Debido a que estas tecnologías han producido nuevas configuraciones de personas cuyo papel es central para el proceso reproductivo, han emergido ambigüedades sobre la atribución de paternidad. Insisto en que dar cuenta de la intencionalidad en la paternidad dentro de cuatro estructuras explicativas gana mayor validez en la medida en que se incrementan las oportunidades de ejercer intención. Extiendo el dar cuenta de la intención usando la explicación de Scanlon sobre el "Valor de la Elección", en la cual la elección tiene un poder de justificación; esto es, por el hecho de haber elegido, uno acepta las consecuencias normativas de su decisión. Los cambios actuales en tecnologías de reproducción significan que existen varias condiciones para elegir; mientras que se mantiene el poder de justificación por el Valor de Elección, el dar cuenta de la intención llega a ser lo suficientemente inclusivo para abarcar el statu quo, plausible incluso en situaciones donde no existe intención o no se expresa.

Palabras clave: padres, estatus de paternidad, reproducción, tecnología reproductiva, técnicas de reproducción asistida

\section{Quem deve ser um pai? Paternidade e a importância da escolha reprodutiva}

Resumo: As várias tecnologias reprodutivas expandiram o poder que as pessoas têm de controlar suas funçôes corporais. Porque estas tecnologias trouxeram novas configuraçóes de pessoas cujo papel é fundamental para o processo reprodutivo, ambiguidades emergiram sobre a atribuição da paternidade. Eu insisto que a consideraçáo intencional entre quatro quadros explicativos para a paternidade ganha mais validade, quando oportunidades de exercer a intenção de aumentam. Eu estendo a consideração intencional, utilizando a explicação de Scanlon, do "Valor de escolha". Scanlon explica que a escolha tem um poder de justificação; ou seja, pelo fato de ter uma escolha, um aceita as consequências normativas de uma decisão. As atuais mudanças em tecnologias de reprodução significam que existem várias condiçôes para escolher. Enquanto mantendo o poder de justificação do valor da escolha, a consideração intencional torna-se suficientemente inclusiva para abranger o status quo, plausível mesmo em situações onde uma intenção não existe ou não é exercida.

Palavras-chave: pais, status de paternidade, reprodução, tecnologia reprodutiva, técnicas de reprodução assistidas

\footnotetext{
${ }^{1}$ Department of Medical Education, School of Medicine, Ewha Womans University, Seoul, Korea Correspondence: clairejungakim@gmail.com
} 


\section{Introduction}

Developments in the technology of reproduction have created new opportunities for many people and, as a result, brought philosophical questions into an area that has hardly been given serious thought. Until recently, the questions and answers concerning parenthood were relatively simple, compare to highly abstract ideas such as justice; people have believe that they can justifiably identify in most cases who can claim parenthood and on what basis the claim rests. However, technological advances and their proliferations, such as assisted reproductive technology (ART) and various contraceptive methods, are triggering events that have not been experienced in human history, and making people consider the essence of parenthood as well. To help resolve the issue of parental responsibility and to draw a line on permissible reproductive action, people need a concept of parenthood founded on a stable basis.

There are four competing frameworks for defining parenthood in general: genetic, gestational, causal, and intentional accounts(1). In the current era of technology that enables people to exert intention, I suggest that the intentional account (in which the intention of an individual involved in the reproductive process plays a crucial role in determining parenthood) has more plausibility. However, the intentional account, like the others, has an inherent weakness of being unable to embrace and explain all cases of reproduction. Certainly, there seem to be many more pregnancies that are not consciously intended by potential parent(s) than those that are intended (and therefore fit the intentional account). I believe that Scanlon's assertion of the Value of Choice(2), which explains the significance of choice and its role in justifying a moral principle, can shed new light on and solve the problem. Identifying the values of reproductive choices and drawing justificatory power from them would help to legitimately assign parental responsibility based on their opportunity to make choices about reproduction. I first start by introducing the four accounts of parenthood and then take a brief look at Scanlon's Value of Choice. I argue that, based on the insight provided by Scanlon's analysis of choice, one can extend the intentional account and reinforce its plausibility.

\section{New conflicts: the need to found parenthood on a solid basis}

A changed reproductive environment raises a serious question as to the conventional way of assigning parenthood and to the justification for such assignment. This is because the power and scope of influence that new technologies trigger are not limited to potential parents, who have already been recognized in the traditional reproductive setting, but extend to new settings that include other people who have not been recognized as potential parents in the traditional way. These new reproductive settings and newly involved parties create situations in which pre-existing norms cannot apply. For example, the clinic setting for ART involves many participants, such as doctors, gamete donors, and surrogate mothers. Not surprisingly, those who are brought in to the process of reproduction by new technologies sometimes conflict with each other about parental rights and responsibility in terms of both their very existence and their extent ${ }^{2}$. When a surrogate mother gives birth, she may claim custody and a dispute with the commissioning couple may ensue. In the case of preventing pregnancy too, there can be a conflict between parties with different intentions, especially when a man and woman in a sexual relationship have the same intention originally but one or other change their mind when faced with unintended consequences, such as an unexpected pregnancy.

Furthermore, we need an account of parenthood to prescribe the boundaries of permissible acts of reproduction. As one does in the development of technology in other areas too, we come to ask

\footnotetext{
${ }^{2}$ Here I primarily focus on parenthood as a responsibility or duty, but eventually this also implies parenthood as a parental right. Because thorough explanation of and justification for this endorsement of parental right lies beyond the scope of this article, I only assert a link between choice, responsibility, and right. These concepts are intimately interconnected, with the enlargement of one triggering the enlargement of the others. I consider the concept of parental right an instrument that is drawn up to guarantee that parents can perform their role without undue interruption from others. My view can be classified as a "priority" thesis according to the classification of Benatar and Archard(3). Explaining the rights and duties of parenthood, Benatar and Archard classify three approaches: the "parental package" thesis; the "no parental right" thesis; and the "priority" thesis. The priority thesis admits that there are parental rights but regards these as subordinate to parental duties. Since I think the right is subordinate to the responsibility, my discussion in this paper concentrates on parenthood as a responsibility.
} 
ourselves whether it is permissible to do what is technically possible. This question, in the area of reproduction, is closely linked with the question of parenthood. One has to ask first, "Do they qualify for parenthood?" before asking, "Is it permissible for them to participate in this reproductive act and create a child?" This is a prospective question that draws a line for justifiable action. In order to answer it, it is necessary to apply the standard explanation for appropriate parenthood and the qualities needed to achieve it.

All these cases raise questions about parenthood. Deciding who, among the involved parties, should be regarded as a parent, and on what basis we should decide their parenthood, becomes more and more important. The significance of answering these questions about parenthood originates, to some extent, from the social need to ensure that newly born future citizens receive adequate care for an adequate length of time. Stable parenthood is crucial for children's growth. Therefore, the social need to provide stability triggers an effort to secure a firm basis for parenthood that is constant even when the status quo is characterized by rapid change.

\section{Four accounts of parenthood}

Four competing perspectives of parenthood have been presented to satisfy the social needs mentioned earlier. These four perspectives are genetic, gestational, causal, and intentional accounts(1). A genetic account relies on the genetic relationship from which the child's genetic component was directly derived. The gestational account relies on the relationship that the child and the provider of their intra-uterine life - namely, the birth mother- have. The causal account relies on the causation of the existence of the child. The intentional account relies on the intention to fulfill the "begetting, bearing, and rearing" of the child(4).

Each account has its own limit in capturing all cases of reproduction. Given the highly developed technology with which one can exert one's reproductive intention, the genetic and gestational accounts seem to face many counter-examples and lose the validity that they once enjoyed. Even though children bear a genetic similarity to their parents in most current families and that similarity is derived from their parents, there are other socially constructed factors, such as society's recognition of the family and genetic contributors' fulfillment of duty. Moreover, there have long been cases of adoption where, without a genetic relationship, other socially constructed factors can constitute sufficient grounds for parenthood. These cases show that genetic factors themselves may have moral significance to a certain extent, but they are not overriding compared with other concepts. For example, in the unusual situation of gamete donation, it is more acceptable for the nature of the account to rely on moral concepts that are adopted in broader areas of our moral life rather than within the restricted area of the family.

The gestational account also suffers from a flaw in justification. Although this account might be seen as having a similarity to the concept of desert or entitlement, which is a familiar concept in moral philosophy, it has different features from most other cases in which the concept of desert or entitlement is applied. Other desert or entitlement-applied conditions only recognize people who put their efforts into what they have decided. At some point in time, there should have been a decision. If there is no choice or decision at all, not even an implicit one, mere input of effort cannot be recognized. Moreover, considering the changed situation of reproduction, there are people who agree to gestate a baby, but not to rear it as their child — for example, a surrogate mother. Here, one should acknowledge that the concept of desert or entitlement is not always applicable to gestation. Therefore, there are significant limitations in applying the concept of desert and justifying gestational accounts.

The causal account blurs the distinction between moral responsibility and causal responsibility. While imposition of parental responsibility as a moral responsibility is one thing, the fact that one has contributed to the causation of human creation is another. We do not always elicit normative outcomes from mere causation. Some normative process has to be combined with the causation. This is clearly shown in the situation where we have to "select" a person to become the parent of a child from the many people who contributed to 
"causing the child"3. For example, in the case of IVF reproduction, more than six people may have contributed to the creation of a new human life: each gamete donor for sperm and egg, surrogate mother, commissioning mother and father, clinician and other medical professionals who assisted the procedure. Obviously, these are too many for all to be the parents of the child. Something that can provide justification of parenthood is needed.

Contrary to the views mentioned earlier, the intentional account is capable of justifying the entitlement of parenthood and consequent parental duties. This is because this view is based on the moral significance of choice, which is largely accepted in moral philosophy as well as in our daily lives. Furthermore, in emphasizing the intention to rear a child, the intentional account is in accordance with the purpose of parenthood, which is to guarantee the welfare of the future generation. However, the intentional account also suffers from criticism that the scope of cases in which it can be successfully applied is too limited. To be sure, there are many cases (or even far more cases) in which potential parents have no intention to beget, bear, or rear a child when they are engaged in sexual acts, although they nevertheless become parents $(5,6)$. How can an intentionalist explain parenthood in these circumstances? I believe Scanlon's idea of the Value of Choice can resolve this problem of intentional account and make the account more inclusive. In the following section, I briefly summarize his concept of the Value of Choice and apply it to parenthood.

\section{The value of choice}

Scanlon's analysis of the relation between choice and responsibility is part of his larger theory of contractualism, or the theory of "what we owe to each other". This means that a contract among parties who are "moved by the aim of finding principles that others, similarly motivated, could

\footnotetext{
${ }^{3}$ Fuscaldo(5) points out this drawback of strictly causal accounts. To overcome it, she insists that two conditions should be satisfied: the consequence needs be 1 . foreseeable, and 2 . to be caused by the causer's free action. By limiting the causal account with these conditions, she narrows the issue down from causal responsibility to moral responsibility. However, contrary to her emphasis on causal relationship, I insist that the stress be put on the intention, or the choice. I further consider the conditions she proposes as the prerequisite for intention or choice.
}

not reasonably reject" (2:5) derives its justification for principle, and presumably for the burden of abiding by that principle, from the fact that the parties had the opportunity to choose. Scanlon(7) first shows the "obvious and immediate significance" of choice, the Value of Choice, and then associates it with responsibility. Because of the generic reasons that "people have for wanting to have what happens depend on the way that they respond when presented with alternatives under the right conditions $(2: 251)^{\prime \prime}{ }^{4}$, we bear a burden following the principle that we had an opportunity to avoid.

Scanlon identifies three values as these generic reasons: instrumental, representative, and symbolic. Instrumental value is the value that we immediately come up with when we think about the Value of Choice. It is instrumentally efficient for us to have an opportunity to choose to realize our future satisfaction. Representative value, Scanlon claims(2:253), is satisfied when one can reflect one's thought, judgment, "taste, imagination, and power of discrimination and analysis through making choices." The example he offers is choosing a gift. Even though the gift might not give the receiver as much satisfaction as if the receiver had chosen the object themselves, the fact that the giver chose the gift represents the giver's attitude to the receiver and the event. Symbolic value means that, by making their own choice, the person is sometimes identified as being a competent adult member of society. Examples of these kinds of choices range from lifelong influences, such as career and marriage, to relatively short-term influences, like a decision making on a medical matter. What Scanlon emphasizes is that the Value of Choice is not limited to mere instrumental value. Representative and symbolic values show that, even when the choice does not seem to contribute to the agent's welfare, satisfaction, or enjoyment of achieving an objective, it still has moral significance.

\section{The condition of choice}

When deriving responsibility from choice, Scanlon(7) identifies two factors in choice - "some-

\footnotetext{
${ }^{4}$ Generic reasons are those that can be generalized to individuals in a situation of a certain kind. To make the principle universal, Scan$\operatorname{lon}(2: 255)$ avoids particularity and use the term "generic reasons".
} 
thing that an agent does": namely, an action, and "what an agent is presented with": namely, a condition. This clarification avoids focusing only on the last step of choice: the explicit consent or the act of choice. The fact that one has a condition to choose plays an essential role in choice and cannot recede into the background. Moreover, Scanlon claims that sometimes the condition itself is sufficient to justify responsibility for the consequence.

According to the Value of Choice account what matters is the value of the opportunity to choose that the person is presented with. If a person has been placed in a sufficiently good position, this can make it the case that he or she has no valid complaint about what results, whether or not it is produced by his or her active choice $(2: 258)$.

Therefore, when trying to recognize the Value of Choice, it is more valid to appreciate the significance of the conditions to choose than to be preoccupied with whether they involve active choice or not. With regard to conditions, Scanlon lists a set of alternatives, their relative desirability, the information available to the agent, and so on. Therefore, whether we have a set of desirable alternatives and adequate information about the alternatives will decide whether we can draw power from the Value of Choice and justify assigning parental responsibility. In other words, the conditions in reproduction will decide the appropriateness of assigning parenthood. Now we can go back to parenthood issues and examine more fully the value and role of choice in reproduction, recognizing the significance of the fact that one has a sufficiently good condition to choose.

\section{The value of reproductive choice}

The Value of Choice also exists in the area of reproduction. Moreover, the importance and far-reaching influence of choice requires one to recognize and consider the value of reproductive choice as paramount, and not be preoccupied by choice's instrumental values.

First, choices in reproduction have an instrumental value that makes the future more likely to be enjoyable for the person who has made the choice. Regardless of what kind of future the per- son wants, it is efficient in terms of the chance to have alternatives and to be able to make a choice. In procreation and contraception too, choice can be an efficient instrument in realizing a potential parent's wish. The role of parent changes the pattern of one's life dramatically. Choice enables one to decide for or against this change in lifestyle pattern by oneself, and thereby to increase the chance of merging one's ideal future with reality. What people choose in dreaming their ideal future is not constrained whether to have a baby (or not to have a baby); it also includes their dream family, their role as parent, and their maturation through the experience of being a parent.

Second, reproductive choices have a representative value. For example, any married couple without children is annoyed by persistently being asked, "Why don't you have a baby?" What is apparent in this case is that the choice of becoming a parent can be representative evidence of the reproductive agent's conformist view. One can also find representative value of reproductive choice in linking the fact of the agent's being a parent to the stable and successful status of the agent. Moreover, having children can represent a person's fundamental values, such as their value judgment on life in this world, which is far more a comprehensive judgment than conformity with existing arrangements or a state of prosperity. It is natural to examine how a future child might feel about their life and this world into which they are born, when one decides whether or not to procreate. This examination leads one to the fundamental question of the value of life as a whole and to the moral requirement to make a choice in accordance with one's view of that fundamental question. For example, it is absurd, or at least selfish, for a pessimistic person who thinks life in this world is not worth living to choose to create a child. Hence, it is valid to consider one's choice on procreation as an opportunity to represent how one judges and values life in this world. In relation to contraception and abortion too, the decision not to have a child shows one's value judgment that it is not desirable for one to have a child now for ethical, economic, or other reasons. Therefore, through making choices, we have an opportunity to express our value judgments to society, our future children, and ourselves. 
Third, reproductive choices have symbolic meanings. In the same way that one can easily find a number of taboos on sexual behaviors in any society, the act of reproduction has been the subject of much symbolic value and is only permitted for adults in most societies. In other words, controlling one's body and desire in reproductive actions, and being responsible men and women, have long been critical aspects of maturity, and thus have had a symbolic meaning. Making a choice on reproductive actions and harmonizing one's choice with social norms shows that one is a competent and independent member of society. The act we are concerned with is not restricted to sexual intercourse, of course. However, bringing a child into this world and taking care of that child have significant meanings in the value system of a society, and this may be the fundamental reason why sexual intercourse is associated with taboos. In this regard, symbolic values can be ascribed accordingly to altered forms and goals of reproduction, such as ART and various methods of contraception.

\section{The condition of reproductive choice}

Even though, as shown earlier, the intentional account successfully draws justificatory power from the Value of Choice, the apparently limited scope of the account has been recognized as a major drawback. It seems obvious that there is an unintended consequence of reproduction that is still the result of a voluntary action. When intention does not exist or is not exerted, but a new human life nevertheless comes into being, the intentional account seems to face trouble and be defeated by the causal account. However, even in this paradigmatic case in which the intentional account seems to reveal its limitations, the significance of the condition itself can provide justification for assigning parental responsibility. In other words, if we extend our focus on the explicit act of intention to include the opportunity to choose, we can have a coherent view that is inclusive enough to embrace the status quo, while we maintain the normative power of the choice.

For many moral agents, the current reproductive environment with its many technologies has become a sufficient condition to choose and the tendency is getting stronger. Reproductive consequences, to a certain extent, are not just foreseeable but also controllable, thanks to the technologies. With this control, it is fair to judge "not doing in certain way even though he could have done otherwise if he had so willed" (8:40) as accepting the certain foreseeable consequence. For example, if a heterosexual couple could have freely talked about their individual wishes and desirable futures in terms of procreation, and then employed reliable contraceptive methods according to their decision, but did not, then one can assume that their inaction or omission is to some extent representing their acceptance of the possible consequence of pregnancy.

It might seem onerous to assume intention to become a parent and rear a child from sex without contraception. Nonetheless, there is second reason to consider current reproductive environment as a sufficient condition to choose. Now we have multiple chances to exert our intention in terms of reproduction. These include the opportunity to reverse the prior intention presented through the prior action or inaction. The couple can reinstate their intention, if becoming parents was not their original intention. In fact, the times when people choose their future in terms of reproduction and parenthood are multiple and sequential. However, we sometimes recognize only some of those times, such as pre-conception decision making, and overlook the fact that potential parents can make their decisions at other times too - for example, during post-conception decision making. In the case of sex without contraception, a couple can exert their intention even after conception, by using the morning-after pill or having an abortion ${ }^{5}$. This can also be the case when the intention is exerted long before the conception. In many conservative societies, or subgroups of society, decisions about marriage and procreation come in a package. Once one makes a decision and enters the "normal" lifestyle of that society, such as a marital life with a partner of the oppo-

\footnotetext{
${ }^{5}$ Of course, it is the case only when each of these alternatives is permitted from society's legal system and one's own value system. And I think that the situation has become permissive and this tendency (of being increasingly permissive) will continue. However, the fact that one have these alternatives can bring about extremely demanding obligation to use the alternative. For example, in the case of preconception negligence, if premises on the moral status of embryo or fetus and on the obligation to revise the former negligence are added, it can imply that the woman has to receive an abortion(9).
} 
site sex, other normal options follow. Procreation and child rearing are two of such normal options. Therefore, we can certainly say that choice about reproduction often occurs long before the actual exertion of intention, when one chooses something other than reproduction, but accompanies reproduction frequently. To summarize, the various and serial options that reproductive technology makes available to us constitute sufficient conditions to choose.

The fact that the number of capable agents in reproduction has increased is also important. In a normative dimension, it is important to consider what a reasonable agent can expect of others and of themselves. This is because one judges the significance of an act, and sometimes the permissibility or blameworthiness of an act, based on reasonable expectations; we compare what happens to us with what we reasonably expected. One should examine first whether one's expectations can be applied universally. As I described earlier, more people have become involved in the reproductive environment. They include couples with azoospermia and ovarian dysfunction. Moreover, the number is likely to increase further. In many countries, Homosexual couples who want biologically related babies have come to realize this desire. These increases will definitely have an impact on the levels of reasonable expectation of people in the reproductive sphere. It means that people not only come to have the sufficient condition to choose but also come to learn that others have the same. Normative consequences follow: people will assume and assign parental responsibility based on the fact of choice.

\section{Conclusion}

The changed reproductive situation supports the intentional account by increasing the chances of people exerting intention, and the number of people who can do so. We can see clearly the plausibility of this framework if we broaden the focus from the pre-conception explicit expression of intention towards various forms of exertion, at various points in time. The problem of "no parent" according to the strict version of intentional account can be solved by recognition of the Value of Choice and the condition of choice in the changed reproductive situation. Therefore, more than at any other time in history, what makes a parent become a parent is the intention to be a parent.

\section{Acknowledgements}

Early versions of this article were presented at the Early Career Scholars Bioethics Workshop by the Department of Bioethics in the National Institutes of Health (NIH), which was held as a preconference workshop of the 19th World Congress of Bioethics 2012. I am particularly indebted to Joseph Millum, especially for his comments on the distinction between parenthood as responsibility and right. 
Who Should be a Parent? Parenthood and the Significance of Reproductive Choice - Claire Junga Kim

\section{References}

1. Bayne T, Kolers A. Toward a pluralistic account of parenthood. Bioethics 2003; 17(3): 221-242.

2. Scanlon TM. What We Owe to Each Other. Cambridge(MA): Belknap Press of Harvard University Press; 1998.

3. Archard D, Benatar D. Introduction. In: Archard D, Benatar D, eds. Procreation and Parenthood: The Ethics of Bearing and Rearing Children, New York (NY): Oxford University Press; 2010: 1-30.

4. Begetting, Bearing, and Rearing In: O’Neill O, eds. Having Children. New York (NY): Oxford University Press; 1979: 25- 38.

5. Fuscaldo G. Genetic ties: Are they morally binding? Bioethics 2006; 20(2): 64-76.

6. Nelson JL. Parental obligations and the ethics of surrogacy: A causal perspective. Public Affairs Quarterly 1991; 5(1): 49-61.

7. Scanlon TM. The significance of choice. The tanner lectures on human values 1988; 8: 149-216.

8. Bentham J, Bowring J. Introduction to the Principles of Moral and Legislation. In: Works of Jeremy Bentham. Vol. 1. 40. Bristol: Thoemmes Press; 1995.

9. Melanson G. How the contractualist account of preconception negligence undermines prenatal reproductive autonomy. Journal of Medicine and Philosophy 2013; 38(4): 420-425.

Received: July 7, 2015

Accepted: September 12, 2015 